\title{
Response of elements and organic matter to PETM extreme thermal event in Kongdian Formation in Dongying depression, Bohai Bay Basin
}

XUAN TANG ${ }^{1}$, ZAIXING JIANG ${ }^{2}$, ZHAOYAO ZHANG $^{1}$

${ }^{1}$ China University of Geosciences, Beijing, China and tangxuan@cugb.edu.cn

Paleocene-Eocene Thermal Maximum (PETM, 60-60.25 Ma) is the extreme heat event in geological period closest to modern, during which the environment temperature onland is higher $\sim 8{ }^{\circ} \mathrm{C}$ than its adjacent time and the second member of Kongdian Formation $\left(\mathrm{Ek}_{2}\right)$ deposited in Dongying depression. The $\mathrm{Ek}_{2}$ is composed by the lower part with gray interbedded sandstone and mudstone with unequal thickness, and the upper part with a high-frequency interbedded red and purple mudstones, siltstone, gypsum, and salt rock.

Core and cutting samples were collected from slope and center of lake, and analyzed with major, trace and rare earth elements anlaysis. Major elements $\mathrm{Si} / \mathrm{Al}, \mathrm{Ca} / \mathrm{Mg}$, $(\mathrm{Al}+\mathrm{Fe}) /(\mathrm{Ca}+\mathrm{Mg})$ ratios show that the climate in early $\mathrm{Ek}_{2}$ appears frequent alternation of dry and wet. During the period of PETM, the major elements content of Kongdian Formation change greatly than early time; after the PETM, the climate entered the long period of gradual drying. The rare earth elements (REE) distribution of sedimentary rocks before and after PETM is also significantly different. There is a weak negative anomaly of Eu in the lower part, which is similar to normal lacustrine mudstone deposited the first member of Kongdian and Eocene Shahejie Formation mudstones, whereas the gypsum-bearing mudstones in the upper part has obvious Eu depletion. It shows that the source of shales in the upper and lower section may be different after PETM. There is a good correlation between the abundance of organic matter and trace elements $\mathrm{V}, \mathrm{Cr}, \mathrm{Mn}, \mathrm{Zn}, \mathrm{Sr}, \mathrm{Co}$, Mo, etc. The contents of $\mathrm{V}, \mathrm{Ni}, \mathrm{Zn}, \mathrm{Sr}$ and other trace elements related to organic matter at the bottom of the lake decreased significantly, which had a positive bias during the PETM period; $\mathrm{Sr} / \mathrm{Ba}$ ratio indicate a detrital origin for the $\mathrm{Ek}_{2}$ shales in the slope and bank of lake, e.g. well W46, and the center part of the lake basin might be contributed by endogenic minerals. 